\title{
UZBROJENIE NA MALOWIDLACH ŚCIENNYCH W KOŚCIELE W LUBECKU
}

SŁowa Kluczowe: broń; ikonografia; datowanie

KEYwords: weapons; iconography; dating

\section{I}

Badania złoconych gotyckich ołtarzy i kunsztownych figur $\mathrm{z}$ bogatych średniowiecznych kościołów trwają od wielu lat. Historycy sztuki od dawna zajmują się rozpoznawaniem warsztatów malarskich funkcjonujących w dużych ośrodkach miejskich takich jak Wrocław, Gdańsk czy Kraków. Jednakże malarstwo gotyckie to nie tylko bogate ołtarze fundowane przez miejskich patrycjuszy. Niejako na marginesie takich inwestycji powstają niewielkie, prostsze, zapóźnione technologicznie i stylistycznie, czasem ułomne artystycznie gotyckie malunki lub rzeźby mające zdobić prowincjonalne kościoły. Jednym z wiejskich kościołów, w którym przetrwały do naszych czasów gotyckie malowidła naścienne jest sanktuarium w Lubecku koło Lublińca na Górnym Śląsku.

W 2009 r. w prezbiterium kościoła wykonano serię odkrywek architektonicznych (Trzos 2010: 237-239). Odsłonięto wówczas gotyckie freski, jak się okazało, pokrywające szczelnie wszystkie ściany i sklepienie kolebkowe chóru świątyni. Na sklepieniu tym przedstawiono Chrystusa w mandorli oraz towarzyszące mu anioły i apostołów. Ściany boczne zaś pokrywa Biblia Pauperum, seria obrazów ilustrująca najważniejsze sceny z życia Jezusa. Dzięki funduszom Śląskiego Wojewódzkiego Konserwatora Zabytków w latach następnych dokonano pełnego odkrycia i konserwacji malowideł (Trzos 2012)1.

\footnotetext{
${ }^{1}$ Pełna dokumentacja po konserwacji znajduje się w archiwum Śląskiego Wojewódzkiego Konserwatora Zabytków w Katowicach. Za jej udostępnienie serdecznie dziękuję.
} 
Data powstania malowideł w Lubecku wydaje się problematyczna. Wstępna ocena dokonana przed odkrywców, a następnie konserwatorów umieszcza czas powstania fresków (Trzos 2012: 309) około 1410 r. Tymczasem nawet pobieżna analiza przedstawień sugeruje, iż jest to datowanie zbyt wczesne. Sądzę, że dokładny opis przedstawionych elementów uzbrojenia pozwoli precyzyjnie określić czas powstania lubeckich fresków. Powszechnie przyjmuje się, że uzbrojenie jest elementem bardzo zmiennym, a więc tzw. dobrym datownikiem (Tokarski 1997). Jednocześnie źródła ikonograficzne wielokrotnie były podstawą analiz bronioznawczych (Kajzer 1974; 1976; Wawrzonowska 1976; Nowakowski 1998a: 11-12)². Opis lubeckich fresków przeprowadzę zgodnie z biblijną chronologią przedstawień.

\section{II}

W scenie Rzezi Niewiniątek widoczna jest grupa uzbrojonych oprawców. Ciała dwóch z nich ochraniają zbroje płytowe. Niestety zniszczenia części kwatery uniemożliwiają rozpoznanie całego rynsztunku. Postać z lewej (Fot. 1: a) posiada folgowe trzewiki, nagolennice, nabiodrki oraz złocone nakolanki. Korpus postaci, zapewne również osłania zbroja płytowa, jednakże zasłonięta została szatą w kolorze żółtym z brązowymi lamówkami. Podobne ubiory ochronne pojawiaja się powszechnie w ikonografii schyłku średniowiecza. Ich celem było ozdabiać żołnierza, ale przede wszystkim być znakiem rozpoznawczym oraz ochroną przed warunkami atmosferycznymi (Przybyłok 2010: 178). Forma widoczna na malowidłach lubeckich - krótki kaftan z krótkim rękawem, znajduje bliskie analogie na Poliptyku Zwiastowania z Jednorożcem z kościoła św. Elżbiety we Wrocławiu z około 1480 (Kochanowska-Reiche 2003: 76; Labuda, Secomska 2004: 285-287) lub Poliptyku Strzegomskim z kościoła joannitów ze Strzegomia. Spod krótkiego rękawa wystaje miseczkowata nałokcica z najwyraźniej przynitowaną kolistą tarczką. Przedramię osłonięte jest zarękawiem składającym się z dwóch blach połączonych zawiasem. Rękę osłania rękawica. Postać ta dzierży długi miecz (Kochanowska-Reiche 2003: 83; Labuda, Secomska 2004: 285-287). Porównując go z typologią E. Oakeshotta (2000: IX, 10, 12, 127, 140145) należałoby uznać, że jest to miecz typu XVa z jelcem typu 3 i głowicą typu G. Na jelec nałożona jest półokrągła skórzana taszka chroniąca głownię przed wpadaniem wody do mieczowej pochwy. Miecze o takiej oprawie wydają się być bardzo popularnymi. Autor klasyfikacji taki styl oprawy wydzielił jako

\footnotetext{
${ }^{2}$ Zagadnieniu badań bronioznawczych w świetle źródeł ikonograficznych poświęcono również konferencję III Spotkanie Bronioznawcze „Ars et Arma”, Łódź 2-3.12.2011, której efektem jest 29 tom Acta Universitatis Lodziensis. Folia Archaeologica.
} 
rodzinę A. Również taszka przy jelcu miecza jest w późnym średniowieczu popularnym rozwiązaniem (Thomas, Fritz 1978: il. 11, s. 15-18). Drugi ze zbrojnych (Fot. 1: b) posiada podobne, lecz pozbawione złoceń płytowe osłony nóg. Pozostała część wizerunku tej postaci uległa zniszczeniu.

W scenie Pojmania, obok Chrystusa i jego uczniów odnajdujemy trzech zbrojnych. Po lewej stronie kompozycji znajduje się żołnierz zakuty w pełną zbroję płytową (Fot. 2: a). Jego głowę ochrania kapalin o sferycznym dzwonie i krótkim, wyraźnie odciętym rondzie. Forma hełmu znajduje liczne analogie w materiale archeologicznym. Kapalin o prostym kształcie, kopulastym dzwonie i nieznacznie szerszym rondzie odnaleziony został we Włocławku (Ławrynowicz 2009). Równie krótkie rondo posiada kapalin szwajcarskiego pochodzenia wyłowiony w miejscowości Murten (Miller, Embleton 1995: 11). Twarz ochrania prawdopodobnie tekstylny kaptur (Gutkowska-Rychlewska 1968: 292-293). Na korpus założony ma napierśnik z wielofolgową szorcą. Płyta napierśnika została ozdobiona trzema kanelami rozchodzącymi się od linii pasa wachlarzowato ku górze. Napierśniki jednoczęściowe kanelowane promieniście pojawiają się około 2 ćwierci XV w. Początkowo ich blachę najczęściej (choć nie zawsze) formowano w formy skubizowane (Blair 1958: 130; Nowakowski 1998b: 84-85; Czechowicz 2003: s. 128-130, il. 16-18). Omawiany napierśnik, a również kolejne widoczne na lubeckich freskach, nie wykazują tej cechy. Stąd wydaje się, iż bliższymi analogiami będą być może elementy zbroi płytowej z przełomu wieków (Nowakowski 1998b: 86). Około 1500 r. powstają liczne napierśniki o obłym kształcie, z wachlarzowatymi kanelami. Dobrymi przykładami będą zachowane napierśniki z Churburga (Scalini 1996: 130) i Rodos (Nicolle 2001: 27) lub rodzime przedstawienia z nagrobków przykładowo Mikołaja Kobylańskiego (Mrozowski 1994: 173). Naramienniki, nałokcice i nakolanki zbroi zostały pozłocone. Postać ta, pomimo wybitnego bogactwa uzbrojenia ochronnego posługuje się jedynie drewnianą pałka. O ile pałka występuje niezwykle powszechnie w ikonografii schyłku średniowiecza (Martyka 2011: 14-34), to w kwestii, czy mogła rzeczywiście być używana przez zakutych w zbroję płytową żołnierzy, zachodzą zasadnicze wątpliwości. Warto zwrócić uwagę na brak tej kategorii broni wśród popisów rot zaciężnych (Bołdyrew 2011: 218-219). Co więcej pałki występują niemal wyłącznie w scenach pasyjnych, przez co należy uznać, iż jej wizerunek ma świadczyć niejako o wulgarności postaci, a mówiąc dokładniej: jej negatywnym charakterze $\mathrm{w}$ tej scenie (Żygulski 1978: 598-599).

Kolejny zbrojny ma założony na głowę nietypowy poczerniony hełm (Fot. 2; b). Ma on formę baniastą z wysoką sterczyną, nasuwającą skojarzenia 
z cerkiewnymi kopułami. Wśród zabytków zachodniej proweniencji trudno odnaleźć podobną formę. Są co prawda znane kapaliny o analogicznym dzwonie (Wap 1994: 125-126; Przybyłok 2009: 136; Ławrynowicz 2009: 180-181), jednakże w tym przypadku wyraźnie brakuje ronda. Stąd za najbliższą analogię można przyjąć okazy typu storczhelme lub pekilhube znane przede wszystkim z zachowanych zabytków z Mielna (Nowakowski 1994: fig. 13) oraz przyłbicy przechowywanej w Muzeum Okręgowym w Toruniu (Głosek, Nowakowski 1980). W najnowszych badaniach nad malowidłami Mistrza Brzeskich Pokłonów Trzech Króli autorstwa M. Głoska i W. Wasiaka rozpoznano podobne, choć wcześniej datowane hełmy w Strzelnikach i Krzyżowicach koło Brzegu (Wasiak 2009; Głosek, Wasiak 2011). Pozwala to umieścić późnośredniowieczne hełmy ze sterczyną również w kontekście Śląska a nie jak dotychczas sądzono wyłącznie Państwa Zakonnego. Uzbrojeniem zaczepnym tego żołnierza jest włócznia o prostym romboidalnym grocie z przymocowanym do drzewca proporcem. Proste groty włóczni występowały u schyłku średniowiecza jako broń bojowa i myśliwska. Podobne do występujących na malowidłach zabytki odnaleziono przykładowo w Namysłowie i Nysie (Marek 2008: 163, ryc. 291, 293).

Ostatni ze zbrojnych (Fot. 2: c) nie posiada uzbrojenia ochronnego, a jedynie dzierży w dłoniach halabardę (Głosek 1998: 44-45). Forma broni przypomina liczne zachowane do dziś zabytki. Bliską analogią jest zabytek z około $1500 \mathrm{r}$. przechowywany w Deutsches Historisches Museum w Berlinie (Müller, Kölling 1981: 241). Również w ikonografii odnajdujemy liczne przedstawienia podobnej broni. Warto w tym miejscu wymienić malowidła ze Strzelnik (Domasławski, Karłowska-Kamzowa i in. 1984: il. 94, 101) lub poliptyk ze Książnic Wielkich (Gadomski 1988: il. 156).

Święty Piotr na malowidle lubeckim wyciaga broń z pochwy by bronić nauczyciela. Niestety ten fragment malatury dotrwał do naszych czasów w złym stanie, przez co widoczna jest jedynie brązowa pochwa broni oraz jej głowica o gruszkowatym kształcie. Schematyczny rysunek może przedstawiać zarówno głowicę typu T, jak i V wg E. Oakeshotta (2000:10).

Kolejnego zbrojnego w pełnej zbroi płytowej widzimy w kwaterze ze scena Chrystusa stojącego przed Annaszem (Fot. 3: a). Za plecami Jezusa stoi żołnierz w płytkiej łebce o sferycznym kształcie. Forma osłony głowy jest prawdopodobnie jedną z najpopularniejszych wśród żołnierzy tego okresu. Wspominają o niej sporadycznie dokumenty związane $\mathrm{z}$ wojskami zaciężnymi i arsenałami miejskimi (Goliński 1990: 14). Obok przedstawień ikonograficznych (Przybyłok 2009: tabl. II-III), do naszych czasów przetrwały również pojedyncze egzemplarze (Engel 1909-1911: 186-187). Hełm ten założony 
jest na tekstylny, dopasowany do twarzy kaptur. Szyję chroni kolczy kołnierz (Grabarczyk 2000: 167). Ochrona ta nie była zapewne równie skuteczna co płytowy podbródek, jednakże, wbrew pozorom, często spotykana. Na korpusie żołnierz nosi napierśnik z czterema wachlarzowato rozchodzącymi się kanelami. Forma napierśnika w ogólnym kształcie i stylu nie różni się od omówionego poprzednio (Nowakowski 1998b: 86). Warto jednakże omówić dokładniej szorcę. Ta składa się z 4 folg i taszek złożonych z kolejnych mniejszych folg. Rozwiązanie to jest relatywnie późne (Nowakowski 1998b: 89-90). Większość napierśników XV w. posiadała taszki zbudowane z pojedynczej blachy chroniącej udo (Boccia 1982: ryc. 189-193, 195, 198-200 i inne; Miller, Embelton 1995: 19). Folgowa forma pojawia się dopiero u schyłku wieku (Blair 1958: 121; Nowakowski 1998b: 90), by w przeciągu XVI w. rozwinąć się i zastapić płytowe osłony uda i kolana (Boccia 1982: 193-195; Hrabatý 2006: 99). Analogiczne do przedstawień z Lubecka szorce odnajdujemy na nagrobkach powstałych w początkach XVI w. - przykładowo Mikołaja Salomona i Andrzeja Szamotulskiego (Mrozowski 1994: 189, 229-230) noszących również analogicznie kanelowane napierśniki. Podobnie jak w poprzednich scenach, tu także autor uznał, że naramienniki oraz nakolanki powinny być pozłocone. Wydaje się natomiast, że postać ma gołe dłonie. Żołnierz uzbrojony jest w halabardę o wachlarzowatym ostrzu i lancetowatym grocie. Drugi ze strażników (Fot. 3: b) Jezusa ma założony na głowę kapalin. Niestety większość jego rysunku została zniszczona, a widoczna pozostała jedynie krawędź ronda. Ciało żołnierza osłonięte jest jedynie cywilnym ubraniem w postaci długiej jaki/robe (Gutkowska-Rychlewska 1968: 292).

Wedle autora malowideł pachołkowie przy przesłuchaniu Jezusa przez Kajfaszem byli zdecydowanie gorzej wyposażeni. Ich jedynym uzbrojeniem ochronnym jest płytki hełm o fantastycznym kształcie czapki frygijskiej (Fot. 4: a). Zatknięty za pasek pachołka czekan reprezentuje typ Ig według M. Głoska (1996: 30 i nast., tabl. IV). Masywny żeleziec posiada krótką osadę i niewielki młotek. Broń tego typu odnajdywana jest relatywnie często w trakcie badań archeologicznych. W kolekcjach muzealnych znajduje się co najmniej kilka egzemplarzy z terenu Śląska, odpowiadających kształtem przedstawieniu z Lubecka, jak np. czekany z Jeleniej Góry (Głosek 1996: 82) i Raciborza (Marek 2008: 170, ryc. 184a-b).

W scenie sądu Piłata kolejni pachołkowie trzymają Jezusa pod ramiona. Jeden z nich pozbawiony jest jakiegokolwiek uzbrojenia (Fot. 5: a). Drugi natomiast ma założoną zbroję podobną do opisywanych powyżej, ze złoconymi osłonami stawów oraz kanelowanym napierśnikiem (Fot. 5: b). W przeciwieństwie 
do pozostałych, ta postać nie posiada hełmu, a jedynie czapkę prawdopodobnie obszytą futrem. W lewej dłoni zbrojny trzyma przypuszczalnie puginał szwajcarski (Müller, Kölling 1981: 37). Basilard sięga od linii pasa do połowy uda, a więc ma około $40 \mathrm{~cm}$ hipotetycznej długości. Podobne puginały odnaleźć możemy w ikonografii przykładowo na obrazie Ecce Homo z około 1500 (Labuda 1979: 216-217; Kochanowska-Reiche 2003: 134) r. z kościoła Mariackiego w Gdańsku. Do naszych czasów przetrwały również oryginalne basilardy o równie okazałej, a nawet większej długości (Schneider, Stüber 1980: 59-64).

Kolejna scena w cyklu ma identyczną kompozycję. Tu również dwóch pachołków trzyma Jezusa przed osądzającym go. Pachołek Heroda Antypasa ma na sobie pełną zbroję płytową (Fot. 6). Niestety zniszczony fragment nie pozwala rozpoznać hełmu. Korpus osłonięty jest kanelowanym napierśnikiem. Linie kaneli rozchodzą się wachlarzowato od linii pasa. Jest ich co najmniej pięć. Szorca napierśnika złożona jest $\mathrm{z}$ wielu folg, przechodzących w folgowe taszki. Podobnie jak w pozostałych przykładach elementy chroniące stawy zostały pozłocone. W tym przypadku najlepiej spośród całego cyklu malowideł widoczne są takie szczegóły, jak forma liścia nakolanka. Płytki, miseczkowaty nakolanek wyposażono w koliste liście. Co zastanawiające, znajdują się one zarówno po zewnętrznej, jak i wewnętrznej stronie nogi. Żołnierz ten posiada również rękawice płytowe. Mają formę dwupalczasta, folgową z krótkim mankietem. Taka forma rękawic pojawia się wśród zachowanych egzemplarzy z przełomu XV i XVI w. (Scalini 1996: 106), nie występuje natomiast w początku XV w. jak chcą datować malowidło wcześniejsi badacze. Brak bogatych zdobień, kanelowania, złocenia brzegów i ich fantazyjnych wycinanek zarezerwowanych dla rękawic z najwyższej półki dobrze koresponduje z charakterem postaci. Pachołek uzbrojony jest poza tym w broń sieczną zawieszoną u lewego boku. Jej większa część jest zasłonięta przez postać, przez co widzimy wyłącznie zdobiony ukośnymi liniami trzewik pochwy. Drugi z pachołków praktycznie pozbawiony jest uzbrojenia. Wyjątkiem jest płytka łepka na jego głowie.

Być może scena skazania przez Piłata umywającego ręce pozwoli uzupełnić naszą wiedzę o formie zniszczonego hełmu z poprzedniej kwatery. Identycznie uzbrojony żołnierz nosi w tym przypadku kapalin o krótkim rondzie, które płynnie przechodzi w koniczny dzwon (Fot. 7: a). Hełm wzmocniono niską ością poprowadzoną po osi symetrii. Drugi z pachołków jest w większości zasłonięty przez postać Chrystusa (Fot. 7: b). Widoczne elementy pozwalają sądzić, że ma założony napierśnik oraz płytowe osłony rąk. Głowę chroni płytka łebka o poczernionej powierzchni. 
Obok scen pasyjnych, w prezbiterium w Lubecku przetrwały również malowidła związane z Apokalipsą oraz świętymi. W glifie okiennym widoczna jest postać św. Katarzyny (Fot. 8), która w dłoni, obok koła, trzyma miecz jednoręczny o silnie zwężającej się ku sztychowi głowni. Miecz prawdopodobnie możemy zaliczyć do typu XV lub XVI wg E. Oakeshotta. Jelec oraz głowica zostały zniszczone i w trakcie konserwacji ślad po nich zniknął. Ciekawie prezentuje się broń trzymana przez jednego z aniołów unoszącego się nad symbolem św. Łukasza w scenach Apokalipsy (Fot. 9). W lewej ręce trzyma on miecz typu XV. Jednoręczna oprawa miecza składa się z jelca typu 3 oraz głowicy w formie krzyża równoramiennego. Na jego powierzchni bocznej widoczny jest również równoramienny krzyż. O ile forma głowni i jelca nie stanowią niczego niezwykłego wśród późnogotyckiego uzbrojenia, to kształt głowicy jest zdecydowanie nietypowy, brak tej formy wśród typów wyróżnionych przez E. Oakeshotta. Natomiast zdobienie krzyżem jest popularnym rozwiązaniem i prostym nawiązaniem do wiary, czy metodą niejako poświęcenia oręża. Stąd też należy sądzić, że zdwojenie symboliki krzyża jest w tym przypadku próbą podkreślenia wyjątkowego znaczenia oręża jako broni apokaliptycznej. W prawej dłoni anioł trzyma zaś topór o żeleźcu typu X wg M. Głoska (1996: 43-46, tabl. IV), osadzony na krótkim toporzysku.

Miecz wychodzący z ust Chrystusa Apokaliptycznego (Biblia: Apokalipsa, 1:16) zalicza się do typu XV wg E. Oakeshotta (Fot. 10). W tym wypadku oprawa składa się z jelca $\mathrm{w}$ typie 5 oraz z kolistej lub dyskoidalnej głowicy (typ G lub R). Brązowy kolor głowicy miał być może symbolizować wykonanie $\mathrm{z}$ innego materiału niż jelec i głownię, przypuszczalnie z brązu. Oprawa miecza wykonana z metali kolorowych występowała zdecydowanie rzadziej niż ze stali, jednakże sporadycznie występują takie wśród bogatszych zabytków (Oakeshott 2000: 135, 181-182; Zdaniewicz 2011: 496-497).

\section{III}

Za najlepszy datownik wśród uzbrojenia przedstawionego na lubeckich freskach należy uznać garnitury zbroi płytowych. Jest to element uzbrojenia relatywnie szybko zmieniający się w czasie. Na to zróżnicowanie wpływał swoisty wyścig zbrojeń, jak również moda. Malarz uznał, że zbroje powinny posiadać elementy złocone. Trudno jednak odgadnąć tok myślenia autora. Czy miało to oznaczać, że byli bogaci, że przywiązywali wagę do przedmiotów zbytkowych? A może to zabieg wyłącznie estetyczny? Niezależnie od powyższego pytania, stylistyka zbroi wydaje się być dostatecznie charakterystyczna, by móc 
ją wydatować. Jak już wspomniałem, zasadniczym problemem jest fakt, iż moda na napierśniki o promienistym kanelowaniu pojawia się dwukrotnie, w 2 ćwierci XV w. oraz na przełomie XV i XVI w. Elementem rozstrzygającym jest moim zdaniem szorca $\mathrm{z}$ folgowymi taszkami, której najwcześniejsze przedstawienia oraz najstarsze znane zabytki pochodzą z przełomu XV i XVI w.

Choć nie jest to elementem zasadniczym tej pracy, chciałbym zwrócić uwagę na ubranie brodatego pachołka w scenie sądu Piłata. Ma on założoną ciemną kurtę sięgającą połowy uda. Ubranie posiada charakterystyczny, wyłożony kołnierz. Jest to element pojawiający się w modzie końca XV w. i będący chrakterystycznym elementem w początkach XVI w. (Kloss 1942: il. 264-265; Gutkowska-Rychlewska 1968: 213).

Tym samym, mając określoną chronologię dzieła, możemy spróbować pokusić się o zarysowanie modelu uzbrojenia, jakie zdaniem autora malowideł noszono na przełomie wieków. Najczęściej zbrojni posiadali wyłącznie hełmy. Były to zarówno płytkie łebki można uznać baniasty hełm ze sterczyną. Obok pachołków wyposażonych wyłącznie w hełm, a nawet tylko w broń zaczepna, autor umieścił na freskach kilku żołnierzy w zbrojach płytowych. W ich skład wchodził napierśnik z szorcą i taszkami, pełne płytowe osłony nóg wraz z folgowymi trzewikami. Ręce osłaniały kompletne płytowe naręczaki oraz rękawice bez palców. Części zbroi chroniące stawy pozłacano. Szyję chroniły kołnierze wykonane z kolczej plecionki.

W skład uzbrojenia zaczepnego pachołków wchodziły halabardy, miecze, czekan oraz prawdopodobnie puginał. Nie należy również zapominać o mieczach w rękach aniołów umieszczonych na sklepieniu prezbiterium.

Ogół uzbrojenia wydają się być o ile nie typowym, to prawdopodobnie występującym w tym regionie w końcu XV w. Należy zatem uznać, że malarz był dobrym obserwatorem swojej rzeczywistości, dzięki czemu zyskaliśmy kolejne źródło do poznania kolorytu tamtych lat i możemy zasugerować zmianę określonego w trakcie prac konserwatorskich czasu powstania fresków.

dr Arkadiusz Przybyłok

Uniwersytet Łódzki

Wydział Filozoficzno-Historyczny

Instytut Archeologii

ul. Uniwersytecka 3

90-137 Łódź 


\section{Bibliografia}

Blair C. (1958), European Armour circa 1066 to circa 1700, B. T. Batsford, London.

Boccia L. (1982), Le armature di S.Maria delle Grazie di Curtatone di Mantova e l'armatura lombarda del '400, Busto Arsizio, Bramante.

Bołdyrew A. (2011), Piechota zaciężna $w$ Polsce $w$ pierwszej połowie XVI wieku, Neriton, Warszawa.

Czechowicz B. (2003), Nagrobki późnogotyckie na Ślasku, Wydawnictwo UW, Wrocław.

Domasławski J., Karłowska-Kamzowa A., Kornecki M., Małkiewiczówna H. (1984), Gotyckie malarstwo ścienne w Polsce, Wydawnictwo Naukowe UAM, Poznań.

Engel B. (1911), Schmiedemarkenproben auf einem mittelalterlichen Helm, „Zeitschrift für Historische Waffenkunde", 5/6, s. 186-187.

Gadomski J. (1988), Gotyckie malarstwo tablicowe Matopolski 1460-1500, PWN, Warszawa.

Głosek M. (1996), Późnośredniowieczna broń obuchowa w zbiorach polskich, IAiE PAN, Warszawa-Łódź.

Głosek M. (1998), Broń drzewcowa i obuchowa, [w:] Uzbrojenie w Polsce średniowiecznej 1450-1500, red. A. Nadolski, Wydawnictwo UMK, Toruń, s. 40-52.

Głosek M., Nowakowski A. (1980), Średniowieczna przytbica z Muzeum Okręgowego $w$ Toruniu. Przyczynek do znajomości bałtyjskiego uzbrojenia ochronnego, „Kwartalnik Historii Kultury Materialnej”, R. XXVII, nr 1, s. 53-61.

Głosek M., Wasiak W. (2011), Nowe spojrzenie na problem przyłbicy typu pekilhube z Torunia, [w:] Cum Arma per Aeva. Uzbrojenie indywidualne na przestrzeni dziejów, red. P. Kucypera, P. Pudło, Wydawnictwo Adam Marszałek, Toruń, s. $126-150$.

Goliński M. (1990), Uzbrojenie mieszczańskie na Ślasku od połowy XIV do końca $X V$ wieku, ,Studia i Materiały do Historii Wojskowości”, t. XXXIII, s. 3-64.

Grabarczyk T. (2000), Piechota zaciężna Królestwa Polskiego w XV wieku, Ibidem, Łódź.

Gutkowska-Rychlewska H. (1968), Historia ubiorów, Ossolineum, Wrocław.

Hrabatý S. (2006), Chladná krása plátové zbroje, Muzeum Východních Čech, Hradec Králové.

Kajzer L. (1974), Węierskie Chronicum Pictum i wartość miniatur jako źródła do historii uzbrojenia, Kwartalnik Historii Kultury Materialnej, R. XXII, nr 1, s. $25-37$.

Kajzer L. (1976), Uzbrojenie i ubiór rycerski w średniowiecznej Małopolsce w świetle źródet ikonograficznych, Ossolineum, Wrocław. 
Kloss E. (1942), Die schlesische Buchmalerei des Mittelalters, Deutscher Verein für Kunstwissenschaft, Berlin.

Kochanowska-Reiche M. (2003), Mistyczne średniowiecze, Bosz, Lesko.

Labuda A. (1979), Malarstwo tablicowe w Gdańsku w 2 poł. XVw., PWN, Warszawa.

Labuda A., Secomska K. red. (2004), Malarstwo gotyckie w Polsce, t. 2, Katalog Zabytków, DiG, Warszawa.

Ławrynowicz O. (2009), Nowo odkryty kapalin z Włocławka na tle porównawczym, „Acta Militaria Mediaevalia”, t. V, s. 176-181.

Marek L. (2008), Broń biała na Ślasku XIV-XVI wiek, Wratislavia Antiqua 10, Instytut Archeologii UW, Wrocław.

Martyka K. (2011), Średniowieczna broń obuchowa z ziem Polski. Maczugi, buławy, kiścienie $i$ cepy, Toruń, maszynopis pracy magisterskiej w archiwum Instytutu Archeologii UMK.

Miller D., Embleton G. (1995), The Swiss at War 1300-1500, Osprey, London.

Müller H., Kölling H. (1981), Europäische Hieb- und Stichwaffen. Aus der Sammlung des Musuem für Deutsche Geschichte, BerlinMilitärverlag der Dt Demokrat Republik, Berlin.

Mrozowski P. (1994), Polskie nagrobki gotyckie, Arx Regia, Warszawa.

Nicolle D. (2001), Knight Hospitaller (2) 1306-1565, Osprey, London.

Nowakowski A. (1994), Arms and armour in the medieval Teutonic Order's State in Prussia, Oficyna Naukowa MS, Łódź.

Nowakowski A. (1998a), Charakterystyka podstawy źródłowej, [w:] Uzbrojenie $w$ Polsce średniowiecznej 1450-1500, red. A. Nadolski, Wydawnictwo UMK, Toruń, s. 9-14.

Nowakowski A. (1998b), Uzbrojenie ochronne, [w:] Uzbrojenie w Polsce średnioweicznej 1450-1500, red. A. Nadolski, Wydawnictwo UMK, Toruń, s. 73-105.

Oakeshott E. (2000), Records of the Medieval Swords, The Boydell Press, Woodbridge.

Przybyłok A. (2009), Przyczynek do poznania hetmów żołnierzy biblijnych w późnośredniowiecznej sztuce Ślaska, [w:] Broń $i$ wojna $w$ dziejach człowieka, red. K. Badowska, W. Wasiak, P. Łuczak, Instytut Archeologii UŁ, Łódź, S. $133-151$.

Przybyłok A. (2010), Testosteron nie tylko w stal odziany, [w:] Seks! Przyjemność, konieczność, czy patologia, red. J. Jagla, Uniwersytet Łódzki, Łódź, s. $170-181$.

Schneider H., Stüber K. (1980), Waffen im Schweizerischen Landesmusuem, Griffwaffen I, Orell Füssli, Zürich.

Thomas B., Fritz J. (1978), Unbekannte Werke spätmittelalterlicher Waffenschmiedekunst in Karlsruhe, „Waffen und Kostümkunde”, t. 20, z. 1, s. 1-18. 
Tokarski W. (1997), Średniowieczne militaria jako wyznacznik chronologii, „Archaeologia Historica Polona”, t. 6, red. J. Olczak, Toruń, s. 55-68.

Trapp O., Scalini M. (1996), Die Churburger Rüstkammer, Magnus Edizioni, Udine.

Trzos A. (2010), Karchowice i Lubecko. „Biblia pauperum” w dwóch wydaniach, „Wiadomości Konserwatorskie Województwa Śląskiego”, t. 2, s. 237-239.

Trzos A. (2012), Sprawozdanie z III etapu prac konserwatorskich w prezbiterium kościoła Wniebowzięcia Najświętszej Marii Panny w Lubecku, [w:] Blaski Średniowiecza, red. B. Klajmon, Wiadomości Konserwatorskie Województwa Śląskiego, t. 4, ŚWKZ, Katowice, s. 309-316.

Wap A. (1994), Kapalin z XIV/XV wieku, „Zeszyty Naukowe Ośrodka Badań Historii Wojskowej Muzeum Wojska w Białymstoku", t. 8, s. 125-126.

Wasiak W. (2009) Identyfikacja średniowiecznych przedstawień ikonograficznych z realnymi egzemplarzami broni, na przykładzie wyobrażeń hetmu typu pekilhube z kościoła w Strzelnikach koło Brzegu, [w:] Broń i wojna w dziejach człowieka, red. K. Badowska, W. Wasiak, P. Łuczak, Instytut Archeologii UŁ, Łódź, s. 117-131.

Wawrzonowska Z. (1976), Uzbrojenie i ubiór Piastów ślaskich od XII do XIV wieku, ŁTN, Łódź.

Zdaniewicz R. (2011), Dwie oktagonalne głowice mieczy z terenu Górnego Ślaska, [w:] Non sensistis gladios. Studia ofiarowane Marianowi Głoskowi w 70. rocznice urodzin, red. O. Ławrynowicz, J. Maik, P. Nowakowski, Instytut Archeologii UŁ [etc.], Łódź, s. 495-504.

Żygulski Z. (jun.) (1978), Średniowieczna zbroja szydercza, [w:] Sztuka i ideologia XV wieku, PWN, Warszawa, s. 597-607.

SUMMARY

\section{ARMAMENT ON THE WALL PAINTING IN THE CHURCH IN LUBECKO}

Paintings revealed in the Assumption of Holy Virgin Mary church in Lubecko during the conservation works have been pre-dated to the beginning of $15^{\text {th }}$ century. However, after military parts shown on the painting were analyzed, this doens't seem to be true anymore. All of depicted soldiers wear full plate armours, composed of plate legs and arms protection some of which have gilded protection parts on their joints. Breastplates are rounded and have radiate cannelures. Soldiers' hips are covered with skirts with foil tassels. That type of breastplates as mentioned above appeared twice in known history of armament: in $2^{\text {nd }}$ half of $15^{\text {th }}$ century and in turn of $15^{\text {th }}$ and $16^{\text {th }}$. Foil tassels suggest rather that second period. This is the type of armour that was popular in that time; numerous tombstones, examples of iconography and single preserved parts of armours are the proof here. 
There are few types of helmets shown on the painting: kettle hats, simple shallow skull caps and rare kind of helmet similar to findings from Torun and Mielno - storczhelme/pekilhube.

All pieces of weapon are depicted as schematically as armours. It is worth to notice that swords have pointy forms, good for stabbing. The most interesting one, handled by one of angels, has an even-armed cross-shaped pommel.

Additionaly to swords, there are also halberds, hammer-axe and misericorde.

Wholeness of the armament seems to be typical for the gothic period. It is highly likely that the author portrayed the reality he knew. 

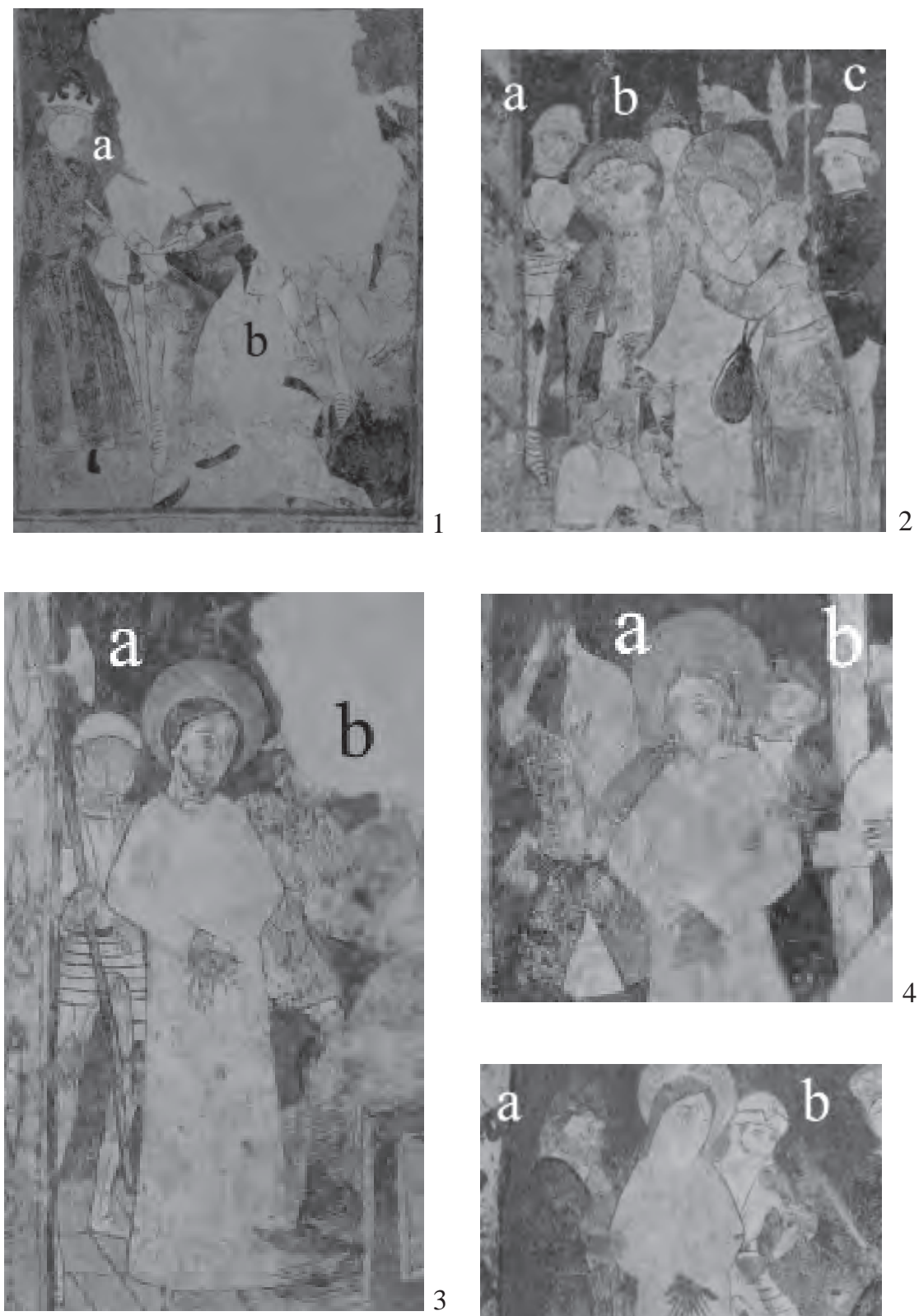

Fot. 1-5. Lubecko, woj. śląskie, kościół Wniebowzięcia NMP (Fot. A. Przybyłok)

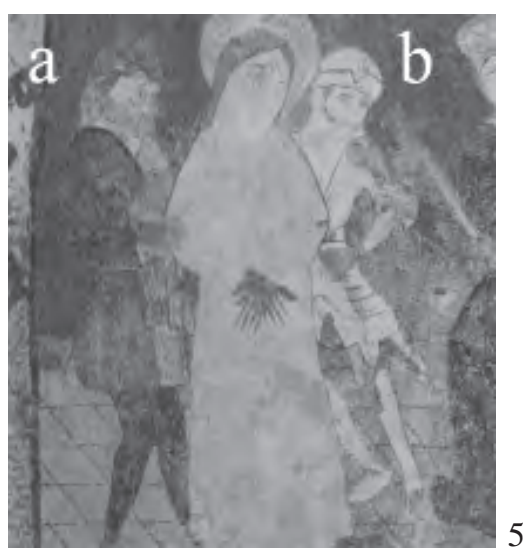



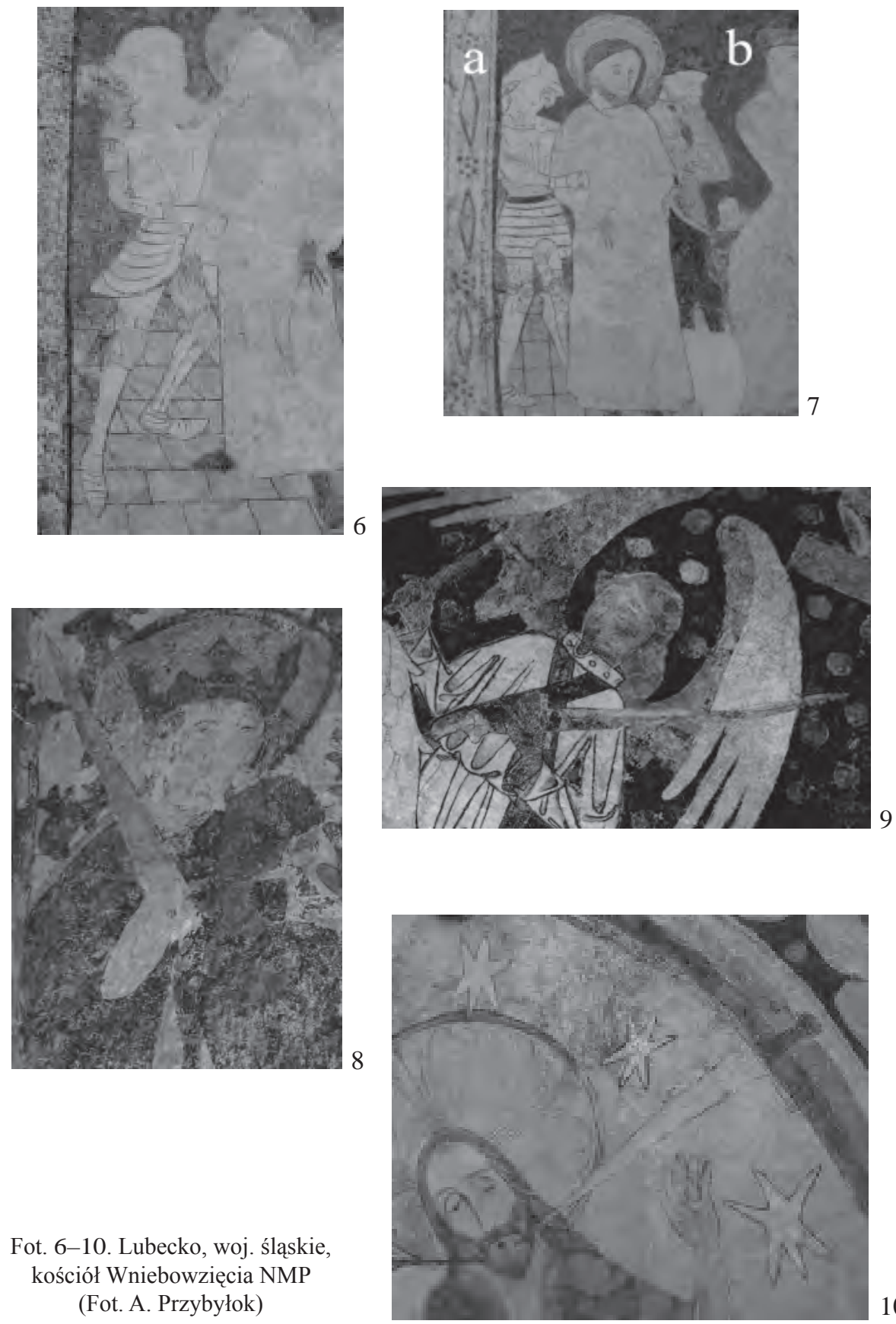

Fot. 6-10. Lubecko, woj. śląskie kościół Wniebowzięcia NMP (Fot. A. Przybyłok) 